\title{
Mass balance of Pizolgletscher
}

\author{
Matthias Huss, Fribourg and Zurich
}

\section{Introduction}

Very small glaciers cover a modest part of the glacierized area in the European Alps. However, their number is considerable. According to the Swiss Glacier Inventory of 1973, 1695 glaciers are smaller than $0.5 \mathrm{~km}^{2}$ (MÜLLER et al. 1976), which corresponds to $82 \%$ of all glaciers in Switzerland (Table 1). Half of the total number of Swiss glaciers is even smaller than $0.1 \mathrm{~km}^{2}$, thus meeting the definition of «very small glaciers» given by KuHN (1995). Very small glaciers represent the largest size class in the Alps, which makes them a relevant object for glaciological investigations.

Very small glaciers are present where mountain peaks are little higher than the regional equilibrium line altitude, or at far lower elevations where extreme accumulation rates occur (KUHN 1995). Due to the lack of significant horizontal movement very small glaciers often are lens or wedge-shaped and display a large thickness to length ratio (KuHN 1995). Furthermore, accumulation rates on small cirque glaciers can be higher by up to a factor of four than the regional winter precipitation due to snow redistribution processes (e.g. EsCHERVetTer \& Rentsch 1995; Kunn 1994).

In some studies in the Eastern Alps, as well as the Mediterranean Mountains, important processes determining the mass balance and the dynamics of very small glaciers were detected (e.g. Gellatly et al.1994; Gonzáles SuÁrez \& Alonso 1994). Interestingly, there appears to be no reports on glaciological studies on very small glaciers in Switzerland in literature. Small glaciers, often situated in cirques and niches below rock walls, are particularly sensitive to snow accumulation changes and are, thus, strongly influenced by wind drift and avalanches. In spite of their limited altitudinal extent, small glaciers often exhibit a clear separation between accumulation and ablation area. Ice motion on steep cirque glaciers probably differs significantly from valley glaciers. The build up of an ice reservoir in the accumulation area may result in a backward rotational movement of the ice mass. Parallel layers of sediment observed on the surface of small glaciers might be explained by shear planes in the ablation area along which material is transported from the glacier bed to the ice surface (KuHN 1995; WEERTMANN 1971). It is debatable whether very small glaciers are good climatic indicators. While for the Swiss Alps Paul et al. (2004) find a rapid decrease in the area of small glaciers, Debeer and Sharp (2007) report no significant changes for the smallest glacier size class in British Columbia, Canada, over the last decades.

With future temperature increase many alpine glaciers will pass into a state of downwasting. Mass balance monitoring of small glaciers can provide important insights into processes governing glacier wastage. Small-scale processes that are also important for the mass budget of large glaciers, can be investigated here in detail. The shape and the location of small ice fields are determined by wind-driven deposition and redistribution of snow (DADIC et al. 2010). Thus, mass balance measurements on small glaciers represent a key to understanding processes determining the spatial distribution of snow accumulation in alpine terrain.

This paper summarizes the first results of a new mass balance monitoring programme set up on Pizolgletscher. The programme was started in 2006 for an indefinite period. So far, mass balance was determined for three years (2006/2007-2008/2009) using a glaciological method based on two field surveys annually. A method to calculate a glacier-wide mass balance based on seasonal point measurements and distributed modelling in daily resolution is presented. The benefit of this method for mass balance determination is illustrated with results that are generally not available within conventional mass balance monitoring programmes. Additionally, changes in glacier area and ice volume based on evaluation of aerial photographs over the last four decades are discussed. Long-term length change measurements are interpreted using a reconstructed time series of the seasonal mass balance.

\section{Study site, monitoring programme and field data}

Pizolgletscher is a very small ice field (glacieret) in the north-eastern Swiss Alps with an area of $0.08 \mathrm{~km}^{2}$ in 2006 (Fig. 1). It is a steep cirque glacier protected on three sides by rockwalls. The glacier extends from 2630 to $2780 \mathrm{~m}$ a.s.l. (Fig. 1).

Mass balance observations on Pizolgletscher were started in 2006. The monitoring programme includes two field surveys per year, one in April and one in September. During the winter survey up to 90 probings of the snow depth were performed all over the glacier; snow density was determined in a snow pit. For measuring the annual balance aluminium stakes with a length of four metres were drilled into the ice (Fig. 1). 


\begin{tabular}{|c|c|c|c|c|}
\hline Size & Number & \% of tot. & Area & \% of tot. \\
\hline $0-0.1 \mathrm{~km}^{2}$ & 1022 & $50 \%$ & $40.1 \mathrm{~km}^{2}$ & $3 \%$ \\
$0-0.5 \mathrm{~km}^{2}$ & 1695 & $82 \%$ & $194.0 \mathrm{~km}^{2}$ & $15 \%$ \\
$0-1.0 \mathrm{~km}^{2}$ & 1846 & $90 \%$ & $298.1 \mathrm{~km}^{2}$ & $23 \%$ \\
\hline
\end{tabular}

Tab. 1: Small glaciers in the Swiss Alps. Selected numbers from the Swiss Glacier Inventory 1973 (MüLLER et al. 1976). The percentage relative to the total of Swiss glaciers is given.

Kleine Gletscher in den Schweizer Alpen. Ausgewählte Zahlen aus dem Gletscherinventar von 1973 (MüLLER et al. 1976). Der Prozentsatz in Bezug auf die Summe der Schweizer Gletscher ist angegeben.

Petits glaciers des Alpes suisses. Numéros sélectionnés sur la base de l'inventaire des glaciers suisses de 1973 (MülLER et al. 1976). Le pourcentage par rapport au total des glaciers suisses est indiqué.

Between two and six stakes could be located and read during the subsequent late summer field survey (Table 2). Over the last three years none of the stakes showed net accumulation. The spatial density of winter accumulation observations (about $900 \mathrm{~km}^{-2}$ ) and summer ablation measurements (about $50 \mathrm{~km}^{-2}$ ) is between one and two orders of magnitude higher than for typical mass balance monitoring programmes in the Alps (e.g. HAEBERLI et al. 2007). Mass balance in water equivalent (w.e.) was calculated using an ice density of $900 \mathrm{~kg}$ $\mathrm{m}^{-3}$ at all locations except for stake 2 and 3 , where firn occurs, assumed to be characterised by a slightly lower density $\left(800 \mathrm{~kg} \mathrm{~m}^{-3}\right)$.

Variations in glacier length have been monitored since 1893 almost annually (GLACIOLOGICAL REPORTS 18812009). Length change is determined by measuring the distance from fixed points in the glacier forefield to the glacier terminus along several parallel lines. The measurements were used to interpret the long-term front variations of Pizolgletscher.

Seven aerial photographs acquired during the last four decades are available for Pizolgletscher $(1968,1973$, 1979, 1985, 1990, 1997, 2006). Glacier outlines were digitized from rectified orthophotographs. Using photogrammetry, high-accuracy Digital Elevation Models (DEMs) with a spatial resolution of $5 \mathrm{~m}$ were established. The overall uncertainty in the elevation information of each DEM due to a combined effect of photogrammetric accuracy, geolocation and interpolation is estimated as $\pm 0.5 \mathrm{~m}$. A DEM with a lower accuracy was obtained from the topographic map of 1961. The DEMs provide ice volume changes in time intervals of five to nine years. Volume change is converted to mass change by assuming an ice density of $850 \mathrm{~kg} \mathrm{~m}^{-3}$ (SAPIANO et al. 1998). This data basis allows an assessment of the changes in glacier area and ice volume over the last five decades.
Meteorological time series are required for running a mass balance model (see below). Air temperature at half-hourly resolution is recorded at an automatic weather station (IMIS - Interkantonales Mess- und Informationssystem) maintained by the Institute for Snow and Avalanche Research (SLF) close to Pizolgletscher (2410 m a.s.1., $0.8 \mathrm{~km}$ from glacier terminus). Data since 2006 has been used here. The study also relies on daily temperature data measured at Säntis (2490 m a.s.l., $32 \mathrm{~km}$ from study site) and daily precipitation totals from Weisstannen (998 m a.s.l., $5 \mathrm{~km}$ from study site) provided by the network of MeteoSwiss.

\section{Changes in glacier area and volume since the 1960s}

The ice thickness of Pizolgletscher was determined in February 2010 based on radio-echo sounding. A Ramac ground-penetrating radar system with an antenna frequency of $100 \mathrm{Mhz}$ was used. In total, 4 kilometres of profiles were realized covering the entire glacier. Ice thickness was evaluated based on a wave speed of $0.168 \mathrm{~m} \mathrm{\mu s}^{-1}$, and corrected for the height of the snow cover. The maximum ice thickness is almost $40 \mathrm{~m}$ (see contour lines in Figure 1b). Interpolation yields a glacier ice volume of $1.2 \times 10^{6} \mathrm{~m}^{3}$ in winter 2009/2010.

The observed changes in ice volume indicate that since 1968 Pizolgletscher has lost roughly $60 \%$ of its mass (inset in Fig. 2). Between 1968 and 1985, however, ice volume and surface area were almost constant. Over the last 40 years glacier area was diminished by two thirds - from $0.24 \mathrm{~km}^{2}$ in 1968 to $0.08 \mathrm{~km}^{2}$ in 2006 (inset in Fig. 2).

Figure 2 illustrates the characteristics of the accumulation distribution of Pizolgletscher for late summer 1973. The pattern is determined by preferential deposition and redistribution of snow (see e.g. LeHNing et 

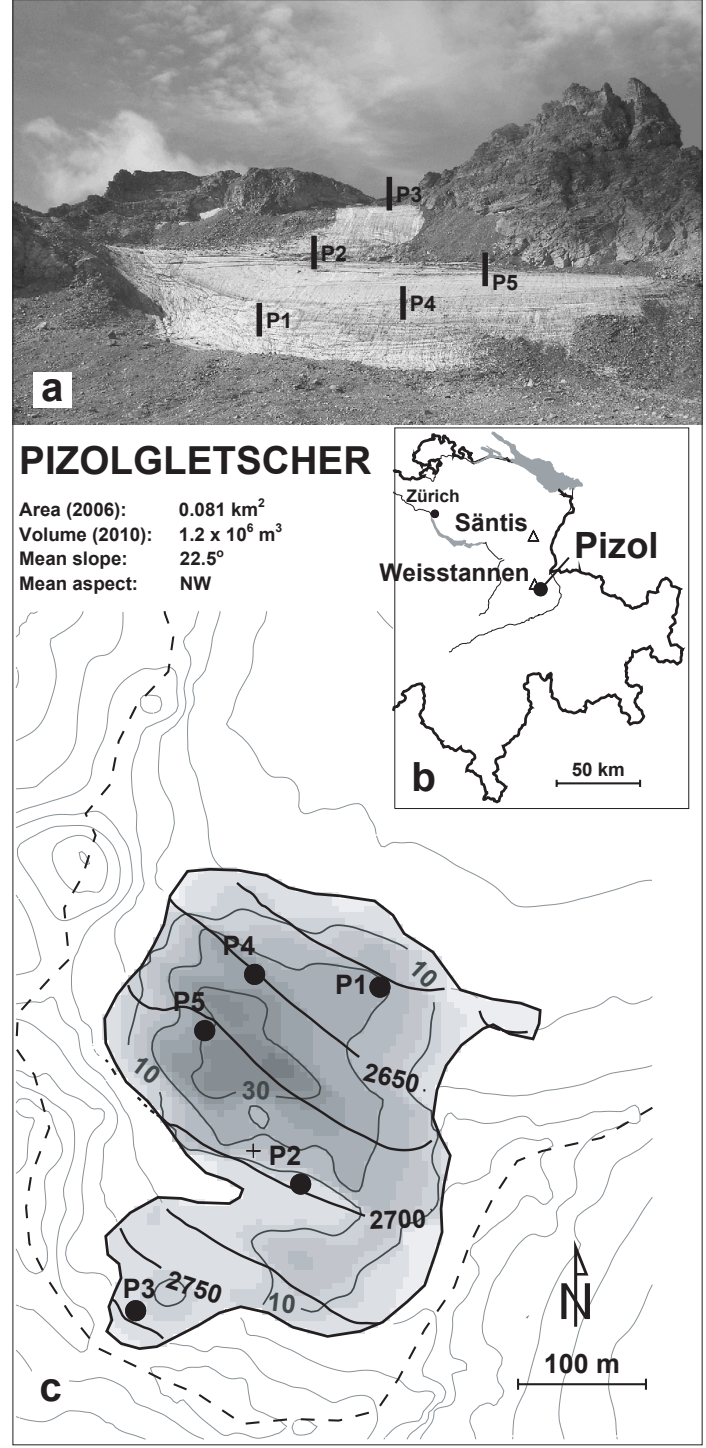

al. 2008). In the centre of the glacier and along several parallel linear structures near the glacier terminus, i.e. where the surface slope is small, snow may still be found at the end of summer (Fig. 2). Due to reduced accumulation in winter the uppermost part and the steep section near the glacier terminus are snow free. According to the aerial photographs this pattern appears to be repeated year after year, which is also confirmed by the direct measurements. Thus, spatial variation in the mass balance of Pizolgletscher - and probably for many glaciers of this size class - strongly differs from a common mass balance distribution that can be described with altitudinal gradients. Pizolglet-
Fig. 1: (a) Front view of Pizolgletscher. The position of the mass balance stakes is shown. (b) Location in Switzerland. Relevant weather stations are marked with triangles. (c) Study site map. The glacier outlines refer to 2006.

Dots show the position of mass balance measurements. The interval of surface contours is $25 \mathrm{~m}$. The dashed line marks the hydrological catchment. The shading and the grey contour lines show the ice thickness measured in February 2010.

(a) Frontansicht des Untersuchungsgebietes; die Position der Messstangen ist markiert. (b) Lage in der Schweiz. Relevante Wetterstationen sind mit Dreiecken bezeichnet. (c) Karte des Gletschers (Ausdehnung 2006).

(a) Vue frontale de la zone d'étude indiquant la position des balises. (b) Localisation en Suisse. Les stations météorologiques utilisées sont marquées par des triangles. (c) Carte du glacier en 2006.

\begin{tabular}{|l|cc|cc|}
\hline \multirow{2}{*}{} & \multicolumn{2}{|c|}{ Winter survey } & \multicolumn{2}{c|}{ Summer survey } \\
& Date & meas. & Date & meas. \\
\hline 2006 & 15 April & 61 & 13 Sept. & - \\
2007 & 2 April & 86 & 3 Sept. & 2 \\
2008 & 2 April & 43 & 25 Sept. & 4 \\
2009 & 7 April & 91 & 13 Sept. & 6 \\
\hline
\end{tabular}

Tab. 2: Field surveys on Pizolgletscher. The number of measurements (meas.) refers to snow probings (winter) and ablation stakes (late summer survey). Feldbegehungen auf dem Pizolgletscher. Die Anzahl der Messungen (meas.) bezieht sich auf Schneesondierungen (Winter) und Ablationsmessungen (Herbstbegehung).

Campagnes de mesures sur le glacier du Pizol. Le nombre de mesures (meas.) se réfère aux mesures de la hauteur de neige (hiver) et aux mesures de l'ablation (visite de terrain de fin d'été).

scher gains most of its mass in positive years in an elevation band around its mean altitude as well as at the glacier terminus.

This implies that an advance of Pizolgletscher does not take place due to a dynamic reaction of the ice mass as for larger glaciers, but due to so called apposition of firn in front of the glacier terminus. Pizolgletscher can thus be termed a "glacier réservoir» (following LLIBOUTRY) with its length changes being related to the mass balance in the corresponding year (HAEBERLI et al. 1989). Due to firn apposition small glaciers can potentially «advance» hundreds of meters in single 


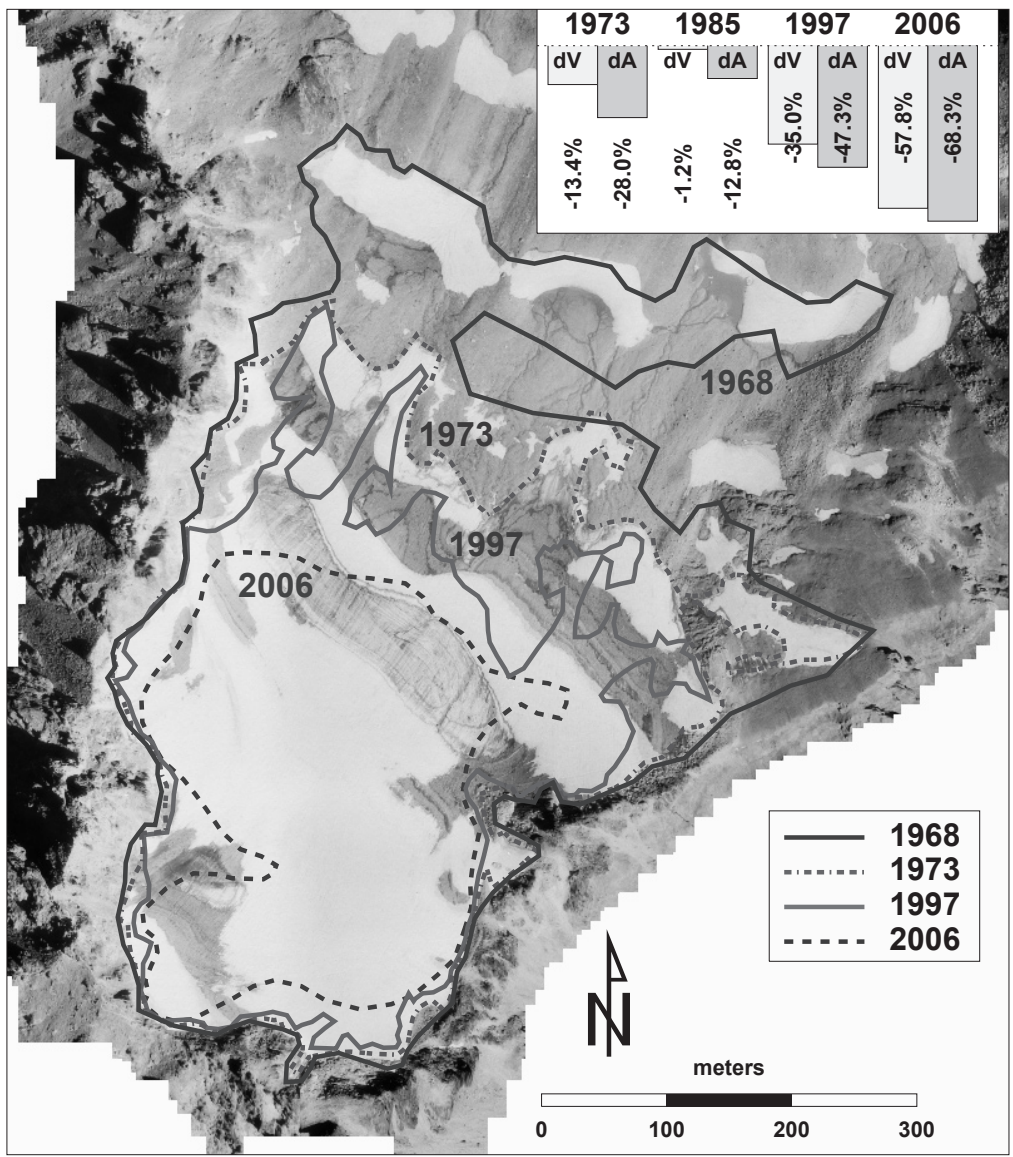

Fig. 2: Orthophotograph of Pizolgletscher (September 1973). Lines indicate the glacier extent in 1968, 1973, 1997 and 2006. The inset shows the change in glacier area $(\mathrm{dA})$ and volume $(\mathrm{dV})$ relative to the year 1968.

Luftbild des Pizolgletschers (September 1973). Die Linien zeigen die relative Gletscherausdehnung in den Jahren 1968, 1973, 1997 und 2006. Oben rechts ist die Veränderung der Gletscherfläche (dA) und des Eisvolumens (dV) gegenüber 1968 dargestellt.

Photographie aérienne du glacier du Pizol (septembre 1973). Les lignes indiquent la surface du glacier en 1968, 1973, 1997 et 2006. L'encart montre le changement relatif de la surface glaciaire (dA) et de son volume (dV) par rapport à l'année 1968.

Photo: M. Huss

years. However, they may lose this length gain equally fast in a succession of only a few warm years because the frontal glacier section only consisted of a shallow multi-year firn field connected to the main ice body. The effects of this process are recognizable in the shape of the glacier margins (Fig. 2). All glacier outlines, excluding 2006, are highly irregular and mainly determined by the extent of multi-year firn in front of the glacier. During the last decade, in contrast, all shallow appositions of firn have melted and the glacier outline of 2006 is given by the body of relatively old glacier ice.

This is also reflected in the measurements of length change (Fig. 3). The data show high rates of retreat and advance in individual years, e.g. in the 1940s or 1960s, respectively. In these periods the length of Pizolgletscher is determined by firn appositions. There are also more stable periods of slow glacier retreat (e.g. 1920s or the last decade), when no firn was 


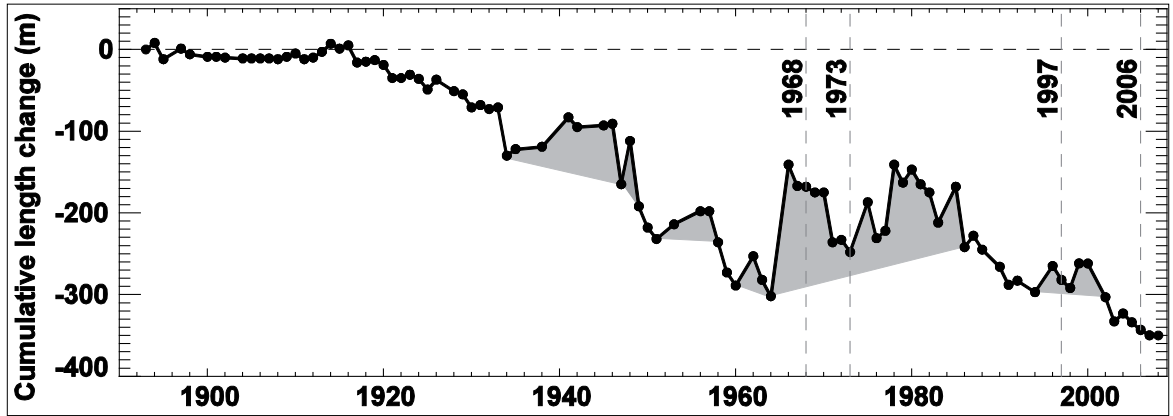

Fig. 3: Measured cumulative length variations since 1893 (Glaciological Reports 1881-2009). Vertical lines refer to the dates of the glacier outlines shown in Figure 2. Shaded areas indicate the presence and the estimated extent of the firn apposition in front of the glacier.

Kumulative Längenänderung (Glaciological RePORTs 1881-2009). Die vertikalen Linien entsprechen den Zeitpunkten der in Abbildung 2 eingezeichneten Gletscherstände. Schattierte Flächen zeigen den geschätzten Umfang der Firn-Apposition vor der Gletscherzunge.

Variations cumulées de longueur (Glaciological Reports 1881-2009). Les lignes verticales se refèrent aux années indiquées sur la Figure 2. Les zones grises indiquent l'étendue estimée du névé alimentant le glacier.

present at the glacier terminus in several consecutive years (Fig. 3).

\section{Determination of glacier-wide mass balance}

The principle of the method to determine the glacierwide surface mass balance, which is outlined in the following, is the constraining of a distributed model with seasonal field observations for each year. Required input data are (i) mass balance measurements at a limited number of points over an arbitrary period of about one year, (ii) snow probings and a snow density profile in early spring, (iii) a digital elevation model and glacier outlines, and (iv) daily air temperature and precipitation measured at nearby weather stations (not necessarily the same). Preferably, precipitation records should be taken from a station close to the study site, temperature data are still appropriate if recorded more distantly from the glacier, but at a similar elevation.

The model provides daily mass balance time series for every grid cell of the glacier and thus allows (1) an extrapolation of measured point mass balance based on an algorithm including approximations for the main processes governing mass balance distribution, (2) the determination of glacier-wide mass balance over e.g. the hydrological year, and (3) the separation of the components of mass balance - accumulation and ablation. This comprehensive set of variables is well suited for further analysis in the context of water resources or climate change.

\subsection{Mass balance model}

A distributed accumulation and temperature-index melt model (Hock 1999; Huss et al. 2008) is applied. Degree-day factors are varied as a function of potential direct radiation in order to account for the effects of slope, aspect and shading. Daily surface melt rates $M=M(x, y, t)$ at day $t$ and for grid cell $(x, y)$ of the DEM are computed by

$$
M= \begin{cases}\left.f_{M}+r_{\text {snow/ice }} I_{p o t}\right) T & : T>0^{\circ} \mathrm{C} \\ 0 & : T \leq 0^{\circ} \mathrm{C}\end{cases}
$$

Where $f_{M}$ denotes a melt factor, $r_{\text {icelsnow }}$ are radiation factors for ice and snow surfaces. Melt over firn surfaces are calculated using $r_{\text {snow. }}$. All factors are assumed to be constant over one year. $I_{p o t}=I_{p o t}(x, y, t)$ is the potential solar radiation. Air temperature $T=$ $T(x, y, t)$ is extrapolated using a constant lapse rate of $-0.0048^{\circ} \mathrm{C} \mathrm{m}^{-1}$ obtained from comparison of nearby weather stations. A correction factor $c_{\text {prec }}$ allows the adjustment of precipitation sums and a threshold temperature $T_{t h r}=1.5^{\circ} \mathrm{C}$ distinguishes snow from rainfall. The spatial variation in accumulation over the glacier is taken into account by using a spatial snow distribution multiplier $D_{\text {snow }}$ derived from snow probings in winter (see below) and terrain characteristics (Huss et al. 2008, 2009). Snow accumulation $C$ is calculated based on the measured precipitation $P_{w s}(t)$ at the weather station occurring at temperatures $T(x, y, t)<$ $T_{t h r}$ as

$$
C(x, y, t)=P_{w s}(t) \cdot c_{\text {prec }} \cdot D_{\text {snow }}(x, y) .
$$




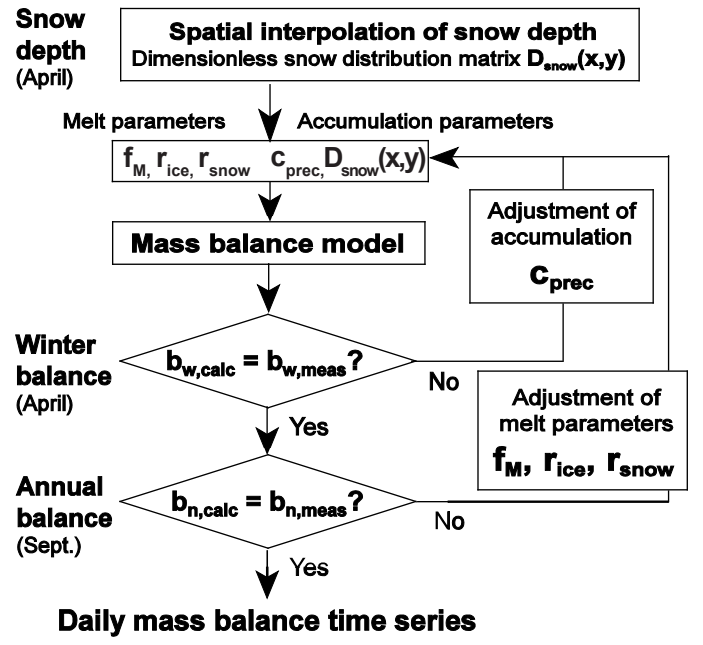

Fig. 4: Schematic representation of the method to determine distributed glacier mass balance in daily resolution. Schematische Darstellung der Methode, mit der die Gletscher-Massenbilanz bestimmt wird.

Schématisation de la méthode permettant de déterminer la distribution du bilan de masse sur une base journalière.

\subsection{Constraining with field data}

The mass balance model is not regarded as a physical model, but as a statistical tool for obtaining a daily temporal resolution based on seasonal field data and spatial interpolation of point measurements supported by a model. Information on the spatial mass balance variability is provided by densely-spaced snow soundings in winter; the temporal evolution of mass balance is given by the means of observed winter accumulation and summer ablation. The procedure described below is performed for every year individually and is visualized in Figure 4:

1. Snow depth (in water equivalent) measured during the winter survey is interpolated spatially over the entire glacier surface. Due to high variability, it is desirable that the snow probings cover as much of the glacier surface as possible and are homogeneously distributed. The dimensionless spatial accumulation map $D_{\text {snow }}$ is derived from the interpolated snow depth. $D_{\text {snow }}$ is normalized to an average of 1 over the glacier surface and varies between 0 (no deposition of snow) and about 2 (twice as much snow as in the glacier-wide average). Thus, processes of preferential deposition of snow, as well as snow drift are approximated in the model via field measurements integrating the entire accumulation season.

\begin{tabular}{|l|c|c|cc|c|}
\hline Stake & Measurement period & $\begin{array}{c}z \\
(\mathrm{~m} \text { a.s.l. })\end{array}$ & $\begin{array}{c}b_{a} \\
(\mathrm{~m} \text { w.e. })\end{array}$ & $\begin{array}{c}b_{w} \\
\left(\mathrm{~kg} \mathrm{~m}^{-3}\right)\end{array}$ \\
\hline $\mathbf{1}-06$ & $13.09 .2006-03.09 .2007$ & 2629 & -2.90 & 1.05 & 374 \\
$\mathbf{2}-06$ & $13.09 .2006-03.09 .2007$ & 2700 & -1.29 & 1.20 & 374 \\
$\mathbf{1}-07$ & $03.09 .2007-25.09 .2008$ & 2629 & -2.09 & 1.20 & 365 \\
$\mathbf{2}-06$ & $03.09 .2007-25.09 .2008$ & 2700 & -0.10 & 1.57 & 365 \\
$\mathbf{2}-07$ & $03.09 .2007-25.09 .2008$ & 2698 & -0.14 & 1.61 & 365 \\
$\mathbf{3}-07$ & $03.09 .2007-25.09 .2008$ & 2765 & -0.66 & 1.79 & 365 \\
$\mathbf{1}-08$ & $25.09 .2008-13.09 .2009$ & 2629 & -1.94 & 1.27 & 385 \\
$\mathbf{2}-06$ & $25.09 .2008-13.09 .2009$ & 2700 & -0.70 & 1.96 & 385 \\
$\mathbf{2}-07$ & $25.09 .2008-13.09 .2009$ & 2698 & -0.01 & 1.93 & 385 \\
$\mathbf{3}-08$ & $25.09 .2008-13.09 .2009$ & 2765 & -0.53 & 1.95 & 385 \\
$\mathbf{4}-08$ & $25.09 .2008-13.09 .2009$ & 2663 & -2.20 & 1.53 & 385 \\
$\mathbf{5}-08$ & $25.09 .2008-13.09 .2009$ & 2682 & -1.13 & 1.71 & 385 \\
\hline
\end{tabular}

Tab. 3: Compilation of annual mass balance $b_{a}$ and winter balance $b_{w}$ data at all stakes. The stake identifier (bold) is specified with the year in which the stake was drilled. The elevation $z$ of the surveyed sites is given. Snow density $\rho_{\text {snow }}$ refers to the winter survey (for dates see Table 2).

Zusammenstellung aller direkten Messungen der Jahres-Massenbilanz $b_{a}$ und der Winter-Massenbilanz $b_{w}$. Die Bezeichnung des Messpunktes (fett) auf Höhe z ist mit dem Jahr, in dem die Stange gesetzt wurde, präzisiert. Die Schneedichte $\rho_{\text {snow }}$ bezieht sich auf die Wintermessung (Zeitpunkt siehe Tabelle 2).

Compilation des données du bilan de masse annuel $b_{a}$ et de l'accumulation hivernale $b_{w}$ pour tous les points d'observation. L'identificateur de balises (en gras) pour l'altitude z est spécifié avec son année d'installation. La densité de neige $\rho_{\text {snow }}$ se réfère à la visite de terrain en hiver (pour les dates voir Tableau 2). 


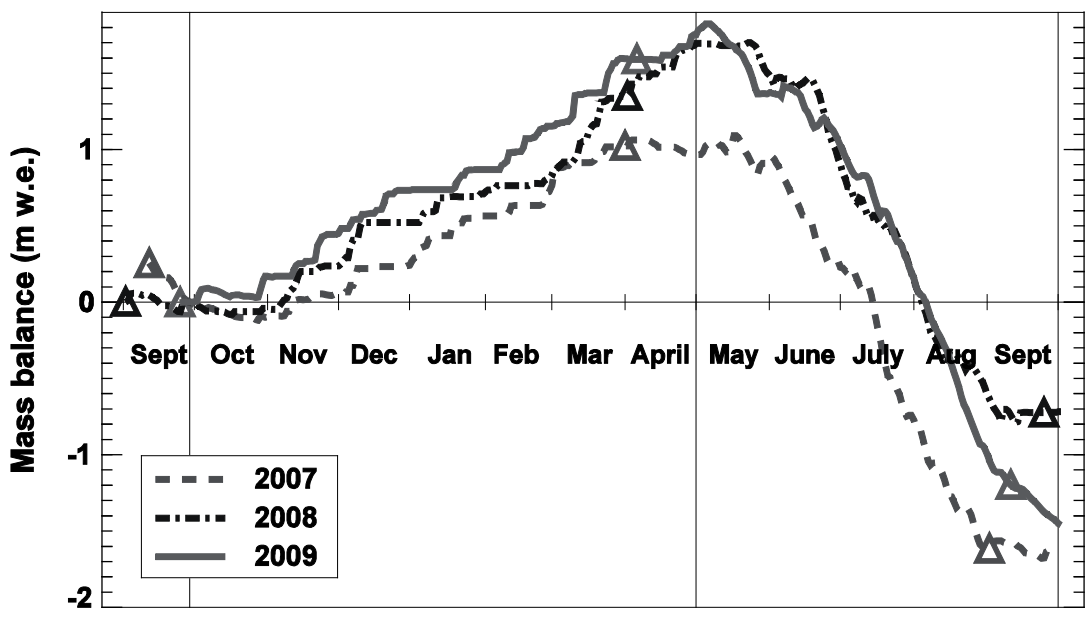

Fig. 5: Cumulative daily mass balance for 2006/2007 to 2008/2009. Symbols indicate the dates of field surveys and vertical lines refer to fixed date periods.

Kumulierte tägliche Massenänderung in den Jahren 2006/2007 bis 2008/2009. Symbole bezeichnen die Zeitpunkte von Feldbegehungen und vertikale Linien die Zeitperioden für die Massenbilanz-Auswertung.

Bilans de masse quotidiens cumulés de 2006/2007 à 2008/2009. Les symboles indiquent les dates des visites ponctuelles de terrain et les lignes verticales les périodes de visite.

2. The model is run over the winter period (given by the dates of the field surveys) with an initial set of melt parameters $f_{M}$ and $r_{\text {icelsnow }}$ and a guess for the precipitation correction factor $c_{\text {prec }}$. As melt is of minor importance in winter, this run is used to calibrate $c_{\text {prec }}$ that scales $D_{\text {snow }}$ for every snow fall event (Eq. 2).

3. As soon as a good agreement of measured and calculated winter accumulation is obtained the model is run over the entire year and the melt parameters are calibrated so that the root-mean-square error between modelled and observed point annual balances is minimized and the average misfit is close to zero (Fig. 4).

\section{Results}

\subsection{Mass balance of Pizolgletscher 2006/2007 to 2008/2009}

The in-situ mass balance measurements indicate that spatial variability in accumulation and ablation on Pizolgletscher is high (Table 3). The difference in annual balance at the stakes 1 and 2 would translate into an altitudinal mass balance gradient of $-2.5 \mathrm{~m}$ w.e. per $100 \mathrm{~m}$, which is higher by a factor of more than three compared to values reported for larger alpine glaciers (Hoelzle et al. 2003; HoInKEs 1970; Huss et al. 2008).
The method described above is applied to determine the glacier-wide mass balance of Pizolgletscher in high temporal and spatial resolution for the hydrological years $2006 / 2007$ to $2007 / 2008$. The model is driven by daily mean air temperature recorded at the IMIS station, and daily precipitation from Weisstannen. Mass balance quantities are evaluated according to the measurement period (Tables 2 and 3) and the fixed date system (Huss et al. 2009). Fixed date annual balance refers to the hydrological year (October 1 to September 30), fixed date winter balance is determined for the period October 1 to April 30 and fixed date summer balance for May 1 to September 30 .

The evolution of mass balance over the three investigated years shows significant differences (Fig. 5). Winter snow accumulation in 2006/2007 was about $30 \%$ lower than in the last two years (Table 4 ) and the melt season started almost one month earlier. Summer melt rates were similar in all years; averaged over the glacier around $3 \mathrm{~m}$ w.e. of snow and ice melt occurred. Mass balance in the hydrological year 2006/2007 was $-1.61 \mathrm{~m}$ w.e., $-0.71 \mathrm{~m}$ w.e. in 2007/2008 and $-1.46 \mathrm{~m}$ w.e. in 2007/2008 (Table 4). This indicates that alone during the three first years of the monitoring programme, Pizolgletscher lost $20 \%$ of its ice volume relative to 2006 .

Figure 5 and Table 4 illustrate the importance of deriving mass balance quantities for common periods. In 


\begin{tabular}{|c|c|c|c|c|c|c|}
\hline \multirow[b]{2}{*}{ Budget } & \multicolumn{2}{|c|}{ Annual period } & \multicolumn{2}{|c|}{ Winter period } & \multicolumn{2}{|c|}{ Summer period } \\
\hline & $b_{a}^{\text {meas }}$ & $b_{a}^{f i x}$ & $b_{w}^{\text {meas }}$ & $b_{w}^{f i x}$ & $b_{s}^{\text {meas }}$ & $b_{s}^{f i x}$ \\
\hline 2007 & -1.84 & -1.61 & 1.14 & 0.99 & -2.63 & -2.59 \\
\hline 2008 & -0.73 & -0.71 & 1.45 & 1.70 & -2.09 & -2.41 \\
\hline 2009 & -1.22 & -1.46 & 1.59 & 1.75 & -2.81 & -3.20 \\
\hline $\begin{array}{l}\text { Accumu- } \\
\text { lation }\end{array}$ & $c_{a}^{\text {meas }}$ & $c_{a}^{f i x}$ & $c_{w}^{\text {meas }}$ & $c_{w}^{f i x}$ & $c_{s}^{\text {meas }}$ & $c_{s}^{f i x}$ \\
\hline 2007 & 1.74 & 1.84 & 1.17 & 1.25 & 0.52 & 0.59 \\
\hline 2008 & 2.47 & 2.34 & 1.46 & 1.79 & 0.87 & 0.55 \\
\hline 2009 & 2.14 & 2.13 & 1.69 & 1.85 & 0.45 & 0.28 \\
\hline Ablation & $a_{a}^{\text {meas }}$ & $a_{a}^{f i x}$ & $a_{w}^{\text {meas }}$ & $a_{w}^{f i x}$ & $a_{s}^{\text {meas }}$ & $a_{s}^{f i x}$ \\
\hline 2007 & -3.58 & -3.44 & -0.03 & -0.26 & -3.15 & -3.18 \\
\hline 2008 & -3.20 & -3.05 & -0.02 & -0.09 & -2.96 & -2.96 \\
\hline 2009 & -3.36 & -3.59 & -0.10 & -0.10 & -3.26 & -3.48 \\
\hline
\end{tabular}

Tab. 4: Compilation of mass balance variables for 2006/2007 to 2008/2009. Results are given for the measurement period (meas) and the fixed date period (fix) for both annual and seasonal time scales. The mass balance components (accumulation $c$ and ablation $a$ ) are reported separately. See Table 2 for dates of the measurement period.

Massenbilanz-Auswertungen für 2006/2007 bis 2008/2009. Die Werte beziehen sich sowohl auf die Messperioden (meas, siehe Tabelle 2) als auch einen konstanten Zeitraum (fix) und wurden für jährliche und saisonale Zeitskalen berechnet. Massenbilanz-Komponenten (Akkumulation $c$ und Ablation a) sind separat ausgewertet.

Compilation des bilans de masse de 2006/2007 à 2008/2009. Les résultats sont donnés pour la période de mesure (meas, voir Tableau 2), et la période à date fixe (fix) et sont évalués pour des périodes annuelles et saisonnières. L'accumulation c et l'ablation a sont représentés séparément.

some years, significant amounts of melt have occurred after the late summer survey. The glacier mass balance terms often differ by more than $0.2 \mathrm{~m}$ w.e. between the measurement period and the fixed date system. A correction of these effects is indispensable if different years or different glaciers are compared to one another.

The mass balance distribution of Pizolgletscher is complex and mainly determined by the accumulation pattern of winter snow (Fig. 6). The altitudinal distribution of both annual and winter balance is similar in all years of the survey but does not follow a linear gradient with elevation (Fig. 7). The least negative mass balances normally occur at stake 2 (Fig. 1c, Table 3). This can only partly be attributed to high amounts of winter snow. The region around stake 2 is protected by a shallow firn coverage that is characterized by higher albedo. By prescribing lower melt factors for firn than for bare ice this effect was captured in the modelling.

\subsection{Seasonal mass balance series since 1961}

The seasonal mass balance of Pizolgletscher is reconstructed for the period 1961 to 2009 based on daily temperature records from Säntis and precipitation from Weisstannen. The mass change calculated by the distributed model is tuned so that the observed ice volume changes are matched (Huss et al. 2008). The eight available DEMs constrain the long-term course of the mass balance evolution in subdecadal intervals. The in-situ field data from the last three years are important for providing information on the spatial mass balance distribution, which is assumed to remain similar over time (e.g. LuCE et al. 1998).

A cumulative mass balance of $-16 \mathrm{~m}$ w.e. is inferred for the period 1961-2009. The mass loss of Pizolgletscher is in line with the long-term glaciological mass balance series of Silvrettagletscher (-13 m w.e.) and Griesgletscher (-30 m w.e.) over the same time interval (Huss et al. 2009). Pizolgletscher experienced mass gains in the 1960s and 1970s (Fig. 8b). This is mainly 


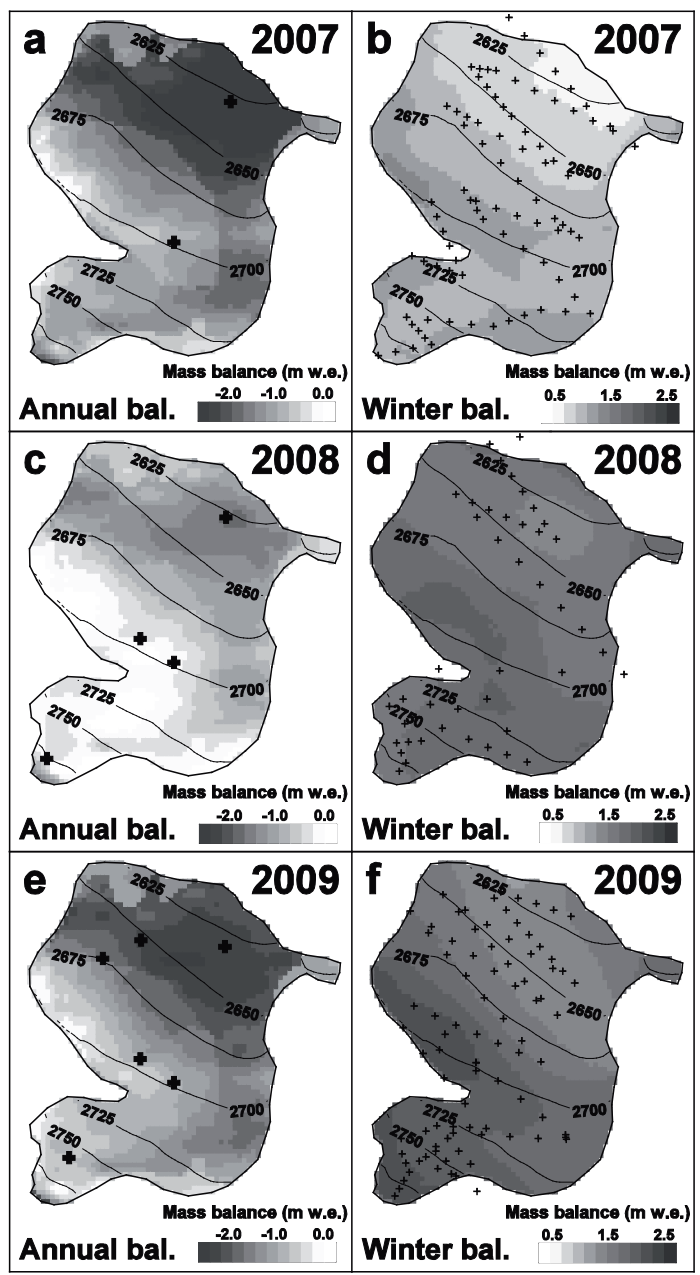

Fig. 6: Spatial distribution of (a, c, e) annual balance and (b, d, f) winter balance for 2006/2007 to 2008/2009 (fixed date periods). Symbols indicate the location of snow probings (winter period) and mass balance stakes (annual period).

Räumliche Verteilung der Jahresbilanz (a, c, e) und der Winterbilanz (b, d, f) in den Jahren 2006/2007 bis 2008/2009. Die Symbole bezeichnen die Position von Schneesondierungen (Winter) und Messstangen (Jahresbilanz).

Distribution spatiale des bilans de masse annuels (a, $c$, e) et des bilans hivernaux $(b, d, f)$ de 2006/2007 à 2008/2009. Les symboles indiquent l'emplacement des sondages nivaux (hiver) et des balises (bilan annuel).

due to reduced melt in summer (Fig. 9). Accelerated mass loss is evident in the last decade. The average mean specific annual balance since 1998 is $-0.99 \mathrm{~m}$

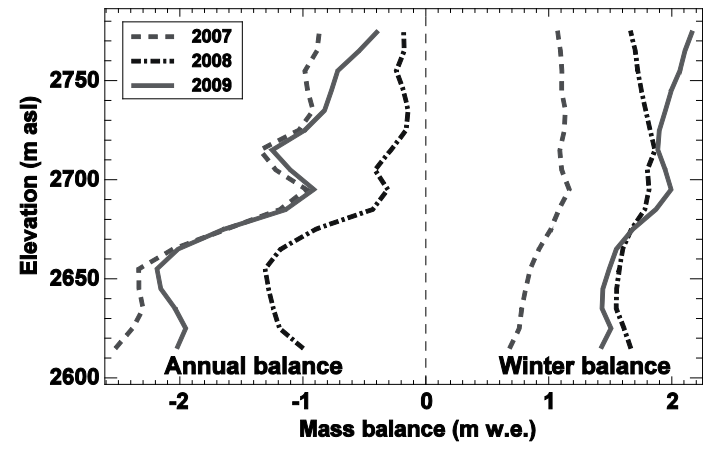

Fig. 7: Altitudinal distribution of fixed date winter balance (positive) and annual balance (negative) for $2006 / 2007$ to $2008 / 2009$

Veränderung der Winterbilanz (positiv) und der Jahresbilanz (negativ) mit der Höhe in den Jahren 2006/2007 bis 2008/2009

Répartition du bilan de masse hivernal (positif) et annuel (négatif) de 2006/2007 à 2008/2009 selon l'altitude

w.e. $\mathrm{a}^{-1}$ and since 2003 even $-1.42 \mathrm{~m}$ w.e. $\mathrm{a}^{-1}$. The low winter balances in the years 2005-2007 are eye-catching (Fig. 9). As Pizolgletscher basically lives on substantial snow accumulation, this reduction has severe consequences for glacier «health» and has resulted in some of the most negative mass budget years since 1961. The most negative summer balance occurred in the year 2003, characterised by extreme heat waves in Europe (SсḦ̈r et al. 2004). The summer balance of 2009 ranks second most negative and is in agreement with the trend towards more summer melting over the last five decades (Fig. 9).

The general course of the cumulative mass change of Pizolgletscher is reproduced by glacier length variations (Fig. 8). The correlation between the two variables is significant according to the F-test on an annual basis. This underlines the assumption that small glaciers react promptly to changes in climate forcing by increasing or decreasing their size. The length change measurements of Pizolgletscher are, however, not well suited as direct indicators for its short-term mass budget because of the low correlation $\left(r^{2}=0.28\right)$.

\section{Concluding remarks}

Direct mass balance measurements on Pizolgletscher have been performed over the last three years. The first results are promising and the monitoring programme will be continued. The mass balance time series of 


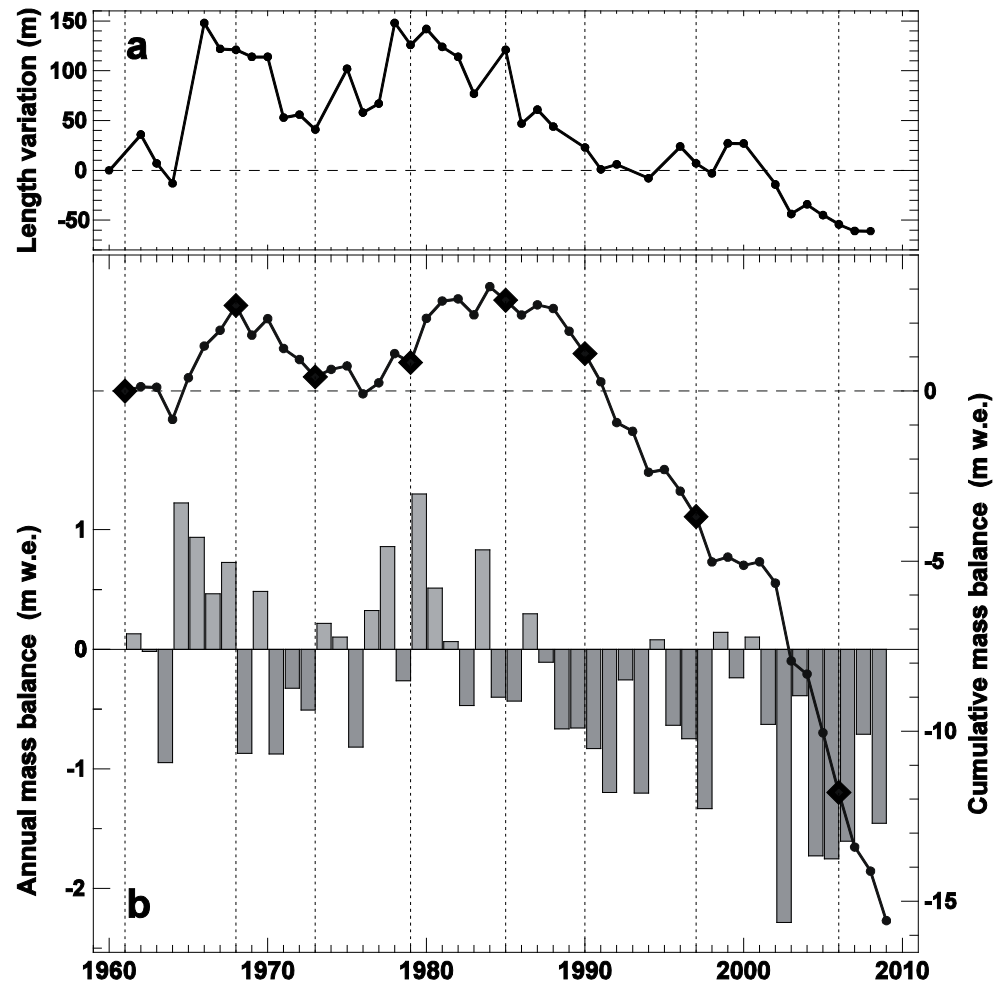

Fig. 8: (a) Cumulative length change of Pizolgletscher since 1961. (b) Calculated time series of annual balance and cumulative mass balance based on ice volume changes. Symbols and vertical lines indicate the timing of digital elevation models (DEMs).

(a) Kumulative Längenänderung seit 1961. (b) Berechnete Jahresbilanz und kumulative Massenbilanz basierend auf beobachteten Eisvolumenänderungen. Die Symbole und die vertikalen Linien bezeichnen den Zeitpunkt von Geländemodellen.

(a) Changement de longueur du glacier du Pizol depuis 1961. (b) Série des bilans de masse annuels et des bilans de masse cumulés issus des changements du volume glaciaire. Les symboles et les lignes verticales indiquent la date des modèles numériques de terrain.

Pizolgletscher provide an example for the response of very small mountain glaciers to climate change. The seasonal field surveys have provided insights into some important factors governing the mass balance of small glaciers, e.g. the strong small-scale variability in accumulation and melting processes, or the importance of snow drift for mass balance distribution. These processes can be studied in detail on Pizolgletscher, because, due to its limited size, its entire surface area can be accessed and covered with mass balance measurements. Understanding small-scale variability in mass balance is one important component for correctly reproducing the mass balance distribution of larger glaciers in numerical models as the same processes can also have significant impacts on wider scales.
The determination of mass balance based on seasonal in-situ measurements in combination with modelling achieves a considerable advantage for the evaluation of the mean specific mass balance in glacier monitoring programmes. The spatial extrapolation of point measurements is performed based on a description of the most important processes determining the distribution of mass balance components in space. The incorporation of weather data for the temporal downscaling allows the projection of mass balance quantities to common periods, as well as a separation of accumulation and ablation. This provides the possibility for an unbiased comparison of different years and glaciers, and a separate analysis of trends in the components of mass balance. For these reasons, the method pre- 


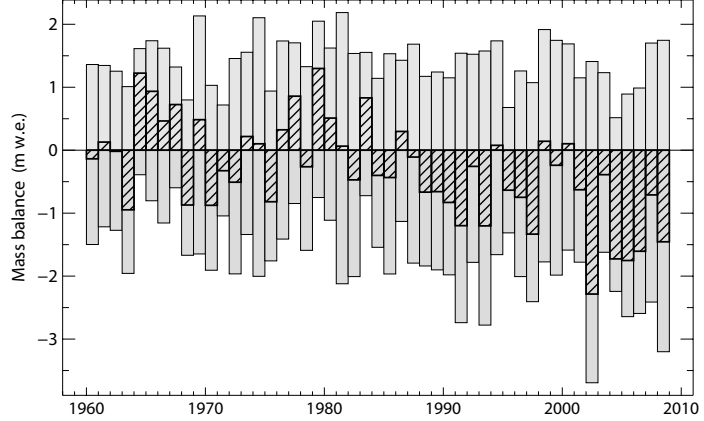

Fig. 9: Fixed date seasonal mass balance time series of Pizolgletscher. Winter balance (positive), summer balance (negative) and annual balance (hatched) is shown.

Saisonale Massenbilanz-Zeitreihen des Pizolgletschers. Die Winterbilanz (positiv), die Sommerbilanz (negativ) und die Jahresbilanz (schraffiert) sind dargestellt.

Série des bilans de masse saisonniers du glacier du Pizol. Le bilan de masse hivernal (positif), estival (négatif) et annuel (hachures) est indiqué.

sented in this paper is recommended for the evaluation of seasonal field data in mass balance monitoring programmes of alpine glaciers. It ensures both the best possible exploitation of information contained in the field measurements and standardized results for the analysis of glacier mass balance under the aspect of changing climatic conditions.

\section{Acknowledgements}

The weather data were provided by MeteoSchweiz and the Institute for Snow and Avalanche Research, Davos. Aerial photograph surveys were provided by Swisstopo. Digital elevation models (DEMs) were established by H. Bösch; field support: A. Bauder, S. Duelli, D. Farinotti, S. Usselmann and M. Werder. Inputs on mass balance observations: M. Funk, A. Bauder; length change measurements of Pizol glacier: A. Hartmann and others.

\section{References}

Dadic, R., Mott, R., Lehning, M. \& P. Burlando (2010): Wind influence on snow depth distribution and accumulation over glaciers. - In: Journal of Geophysical Research 115, F01012.

Debeer, C.M. \& M.J. Sharp (2007): Recent changes in glacier area and volume within the southern Canadian Cordillera. - In: Annals of Glaciology 46, 1:215-221.

Escher-Vetter, H. \& H. Rentsch (1995): The behav- iour of the Bavarian glaciers: results from surveying and mass balance modelling. - In: Zeitschrift für Gletscherkunde und Glazialgeologie 31, 1-2: 181-187.

Gellatly, A.F., Smiraglia, C., Grove, J.M. \& R. LATHAM (1994): Recent variations of Ghiacciaio del Calderone, Abruzzi, Italy. - In: Journal of Glaciology 40, 136: 486-490.

Glaciological Reports (1881-2009): The Swiss glaciers, 1880-2004/05, No. 1-126, Yearbooks of the Cryospheric Commission of the Swiss Academy of Sciences (SCNAT), published since 1964 by the Laboratory of Hydraulics, Hydrology and Glaciology (VAW) at the Federal Institute of Technology (ETH) Zurich.

Gonzáles SuÁrez, J. \& V. Alonso (1994): Glaciers in Picos de Europa, Cordillera Cantábrica, northwest Spain. - In: Journal of Glaciology 40: 198-199.

Haeberli, W., Müller, P., Alean, P. \& H. Bösch (1989): Glacier changes following the Little Ice Age - a survey of the international data basis and its perspectives. - In: Oerlemans, J. (ed.): Proceedings of the Symposium on Glacier Fluctuations and Climate Change, held in Amsterdam, 1-5 June 1987. - Kluwer Academic Publishers: 77-101.

Haeberli, W., Hoelzle, M. \& M. Zemp (eds) (2007): Glacier Mass Balance Bulletin No. 9 (2004-2005). - Glaciology, Geomorphodynamics \& Geochronology, Department of Geography, University of Zurich.

Hock, R. (1999): A distributed temperature-index iceand snowmelt model including potential direct solar radiation. - In: Journal of Glaciology 45, 149: 101-111. Hoelzle, M., Haeberli, W., Dischl, M. \& W. Peschke (2003): Secular glacier mass balances derived from cumulative glacier length changes. - In: Global and Planetary Change 36, 4: 295-306.

HoInkes, H. (1970): Methoden und Möglichkeiten von Massenhaushaltsstudien auf Gletschern.-In:Zeitschrift für Gletscherkunde und Glazialgeologie 6, 2: 37-90.

Huss, M., BAuder, A. \& M. Funk (2009): Homogenization of long-term mass balance time series. - In: Annals of Glaciology 50, 50: 198-206.

Huss, M., Bauder, A., Funk, M. \& R. Hock (2008): Determination of the seasonal mass balance of four Alpine glaciers since 1865. - In: Journal of Geophysical Research 113, F01015.

KunN, M. (1994): Der Mieminger Schneeferner, ein Beispiel eines lawinenernährten Kargletschers. - In: Zeitschrift für Gletscherkunde und Glazialgeologie 29, 2: 153-171.

Kunn, M. (1995): The mass balance of very small glaciers. - In: Zeitschrift für Gletscherkunde und Glazialgeologie 31, 1-2: 171-179.

Lehning, M., Löwe, H., Ryser, M. \& N. Raderschall (2008): Inhomogeneous precipitation distribution and snow transport in steep terrain. - In: Water Resources Research 44, WO7404.

Luce, C.H., Tarboton, D.G. \& K.R. Cooley (1998): The influence of the spatial distribution of snow on 
basin-averaged snowmelt. - In: Hydrological Processes 12, 10-11: 1671-1683.

Müller, F., CAflisch, T. \& G. Müller (1976): Firn und Eis der Schweizer Alpen. - Gletscherinventar No. 57, Geographisches Institut der ETH Zürich, Zürich.

Paul, F., Kä̈̈в, A., Maisch, M., Kellenberger, T. \& W. HAeBerli (2004): Rapid disintegration of Alpine glaciers observed with satellite data. - In: Geophysical Research Letters 31, L21402: 1-4.

Sapiano, J., Harrison, W.D. \& K.A. Echelmeyer (1998): Elevation, volume and terminus changes of nine glaciers in North America. - In: Journal of Glaciology 44, 146: 119-135.

Schär, C., Vidale, P.L., LÜThi, D., Frei, C., HäBerli, C., Liniger, M.A. \& C. Appenzeller (2004): The role of increasing temperature variability in European summer heatwaves. - In: Nature 427: 332-336.

WeERTMAn, J. (1971): Shear stress at the base of a rigidly rotating cirque glacier. - In: Journal of Glaciology 10, 58: 31-37.

\begin{abstract}
Mass balance of Pizolgletscher
Half of the glaciers in the Swiss Alps are smaller than $0.1 \mathrm{~km}^{2}$. Despite this, the mass budget of small glaciers and their response to ongoing climate change is rarely studied. A new mass balance monitoring programme on Pizolgletscher $\left(0.08 \mathrm{~km}^{2}\right)$ in north-eastern Switzerland was started in 2006. This paper presents first results and describes a new approach to determining the mass balance of glaciers. Seasonal field observations are interpreted using a distributed mass balance model in daily resolution that allows spatial inter- and extrapolation of sparse data points and the calculation of mass balance over arbitrary time periods. Evaluation of aerial photographs acquired in subdecadal intervals since 1968 allows inclusion of data on changes in glacier area and ice volume, contributing towards a long-term reconstruction of Pizolgletscher's mass balance. The analysis revealed fast mass loss over the last three years with annual balances of $-1.61 \mathrm{~m}$ w.e. in 2006/2007, $-0.71 \mathrm{~m}$ w.e. in 2007/2008, and $-1.46 \mathrm{~m}$ w.e. in 2008/2009 and high spatial variability of mass balance on Pizolgletscher.
\end{abstract}

Keywords: glacier mass balance, climate change, monitoring programme, accumulation, modelling

\section{Zusammenfassung: Massenbilanz des Pizolgletschers}

Die Hälfte der Gletscher in den Schweizer Alpen ist kleiner als $0.1 \mathrm{~km}^{2}$. Dennoch wird die Massenbilanz kleiner Gletscher und ihre Reaktion auf den Klimawandel selten untersucht. Ein neues Massenbilanz-Monitoring-Programm wurde im Jahr 2006 am Pizolgletscher $\left(0.08 \mathrm{~km}^{2}\right)$, Nordostschweiz, aufgenommen. Dieser Artikel präsentiert erste Ergebnisse und beschreibt eine neue Methode, um die Gletscher-Massenbilanz zu bestimmen. Die Daten der saisonalen Feldbegehungen werden mit einem Modell ausgewertet, das die Interund Extrapolation von spärlichen Datenpunkten und die Berechnung der Massenbilanz über einen beliebigen Zeitraum erlaubt. Die Auswertung von sieben Luftbildern seit 1968 ermöglicht zudem eine Rekonstruktion der langjährigen Veränderungen der Gletscherfläche und des Eisvolumens. Die Analyse der Daten der letzten drei Jahre zeigt einen schnellen Massenverlust mit jährlichen Bilanzen von -1.61 m w.e. im Jahr 2006/2007, $-0.71 \mathrm{~m}$ w.e. für $2007 / 2008$ und $-1.46 \mathrm{~m}$ w.e. für $2008 / 2009$. Die räumliche Verteilung der Massenbilanz auf dem Pizolgletscher ist sehr variabel.

Schlüsselwörter: Gletscher-Massenbilanz, Klimawandel, Gletschermonitoring, Akkumulation, Modellierung

\section{Résumé: Bilan de masse du glacier du Pizol}

Bien que la moitié des glaciers suisses ait une surface inférieure à $0,1 \mathrm{~km}^{2}$, le bilan de masse de ces petits glaciers et leur réponse au changement climatique sont rarement étudiés. Un nouveau programme portant sur le bilan de masse du glacier du Pizol $\left(0,08 \mathrm{~km}^{2}\right)$, au nord-est de la Suisse, a été initié en 2006. Cet article présente les premiers résultats de ce programme et esquisse une nouvelle méthode permettant de déterminer le bilan de masse total du glacier. Des observations saisonnières de terrain sont interprétées en utilisant un modèle de distribution des bilans de masse sur une base journalière qui permet l'interpolation et l'extrapolition des rares points de données disponibles ainsi que le calcul du bilan de masse sur des périodes choisies. L'évaluation de sept photographies aériennes depuis 1968 permet de reconstruire à long terme les changements de la surface et du volume glaciaires. Les analyses révèlent une perte rapide de masse au cours des trois dernières années avec des bilans annuels de $-1,61 \mathrm{~m}$ équivalent en eau (w.e.) en 2006/2007, $-0,71 \mathrm{~m}$ w.e. en 2007/2008 et $-1,46$ m w.e. en 2008/2009. Le bilan de masse du glacier du Pizol présente une grande variabilité spatiale.

Mots-clés: bilan de masse glaciaire, changement climatique, monitoring des glaciers, accumulation, modélisation

Dr. Matthias Huss, Department of Geosciences, University of Fribourg, Geography Unit, Chemin du Musée 4, CH-1700 Fribourg, Switzerland; Laboratory of Hydraulics, Hydrology and Glaciology (VAW), ETH Zurich, CH-8092 Zurich, Switzerland.

e-mail:matthias.huss@unifr.ch

\section{Manuskripteingang/received/manuscrit entré le} 12.1.2010

Annahme zum Druck/accepted for publication/accepté pour l'impression: 13.7.2010 